\title{
Gamification of design process in interior architecture education: Who? with whom? where? how?
}

\author{
Gülsüm Damla Aşkın 1,* \\ ${ }^{1}$ İstanbul Şehir University, 34865, Turkey
}

\begin{abstract}
The design process in Interior Architecture education is the basis of all the studio courses and design-oriented courses. In this process, it is important for students to develop their creative thoughts and find different ideas. Students find it difficult to produce creative design ideas. As well as producing ideas, students also have difficulty in determining problem status and performing user analysis. In this respect, implementation of different methods and activities are important in the process. One of these methods is the integration of gamification into the design education. This education method was conducted as a workshop with a group of Interior Design students during the Spring term of 20182019 in İstanbul Şehir University. The students who took the project course for the first time were included in the research. In the workshop, firstly, the game "Who? With Whom? Where? How?" was played manually, and the user ID was defined. Secondly, the results of the game were converted to the function scheme. After the study, a survey was conducted with the students. It was observed that the method of gamification increased the motivation of the students and offered more than one alternative in design process compared to the traditional thinking methods.
\end{abstract}

\section{Introduction}

In every stage of Interior Architecture education, especially in the studio courses where the project is produced, the design process is utilized. The design process consists of defining a problem, producing solutions and developing the product. The first stages of the design process are the generation of ideas and the determination of the problem situations. Students should also consider user requirements when generating ideas and analyzing problem situations. The design process in the studio classes is important for the students to know the problem well, analyze the user and incorporate their own point of view into the design. All the students benefit from the same stages, but all are expected to produce different and original projects. Students who take project courses for the first time have more difficulty than other courses at these design stages. Therefore, different methods are applied to facilitate students' adaptation to design studios and idea production process is

\footnotetext{
*Corresponding author: damlaaskin@sehir.edu.tr
} 
important. The fact that the studio environment enables different activities such as seminars, workshops and competitions contributes to the originality of the ideas produced.

The design process in Interior Architecture Education includes formal and informal methods. In this study, a new method that can be used in the design process, which is a part of Interior Architecture education, is suggested. This method involves integrating gamification as an informal method that contributes to spontaneous learning within formal education methods and the use of this method in the design process. The design process consists of determining, evaluating and applying the necessary information by determining the problem. In this study, the stage of the analysis of the necessary information by determining the problem was supported by the game "Who? With Whom? Where? How?". Gamification is the addition of abstract designs to real life. This situation can contribute to the problem-solving process and be used as a tool in the process of problem determination. The aim is to increase the motivation of students and contribute to the design education. Gamification is both an interdisciplinary dimension in design education and a funny and creative activity for students. The gamification of education gives students a practical design approach. Thus, a new learning method emerges in the design process of Interior Architecture education.

The research was conducted as a workshop with a group of Interior Design students (12) during the Spring term of 2018-2019 in İstanbul Şehir University. The students who took the project course for the first time were included in the research. Upper class students were excluded. In the workshop, firstly, the game "Who? With Whom? Where? How?" is played manually and the user ID is defined later after being converted to the function scheme. After the study, a survey was conducted with the students. Student opinions were taken about the use of gamification for educational purposes in the design process.

\section{Gamification and interior architecture education}

The design process in Interior Architecture education is based on heuristic methods. The design does not have any formula. Therefore, it is different from the verbal and numerical courses learned in high school. This difference makes it difficult for students to learn design process and produce unique projects in studio courses. Many researchers state that the students receiving Interior Design education mostly have difficulty in studio courses in the first year when the design process is learned [1-8]. Another reason for this difficulty is the formal education system they were previously used to [9]. Various methods such as painting, music, book and game are used in order to enable the students to adapt themselves to design education without having difficulty and getting bored. In this way, the formal education that students receive is supported by informal methods. Including gamification into the design process as a manual game also reveals a new educational method.

The term of gamification was first defined by Nick Pelling as a fast and enjoyable transfer of electronic transactions through game [10]. Karl M. Kapp expresses gamification as a tool for game-based thinking, gathering together, encouraging for learning, motivation and problem-solving [11]. Gamification refers to a method that has objectives such as education, entertainment, experience, motivation, thinking and problem-solving by gathering different disciplines together with game. According to the researches of Kapp, instructional games contribute to high-level thinking skills and motivations of students are increased compared to the traditional learning methods [11]. The reason why game increases motivation in people is that it hosts feelings of challenge, fantasy and curiosity [12].

Gamification is used in all design-focused disciplines to increase students' motivation and contribute to learning at all the stages of education from kindergarten to university. The integration of game into education emerges with the idea of game-based learning. The 
course subjects are taught through game. The first objective of these games is education but they have not lost their entertainment aspect [13]. Lee and Hammer argue that the combination of education and gamification resembles the combination of peanut butter and chocolate. They state that a very different and much more delicious result will emerge from the combination of these two delicious tastes [14]. Gamification in Interior Architecture education is the inclusion of abstract designs in real life in the design process. This situation can be used as a tool in the problem determination process; it also contributes to the problem-solving process. Gamification not only brings an interdisciplinary dimension to design education but also provides an enjoyable and creative activity for students. Gamification of education provides students with a practice-based design approach. Thus, a new learning method emerges in the design process in Interior Architecture education. To facilitate the adaptation of students, who have started receiving Interior Architecture education, to the design process and to contribute to the problem-solving process are among the aims of gamification.

\section{Method}

The design process consists of determining the problem situation, collecting, evaluating and applying the necessary information. The research was conducted as a workshop with a group of students consisting of 12 Interior Design students during the Spring term of 20182019 in İstanbul Şehir University. The students who took the project course for the first time were included in the research. Upper class students were excluded. In the workshop, first, 'Who? With Whom? Where? How?' game is played manually and the user ID is defined later converted to the function scheme. After the workshop, a survey was conducted and the students' perspective on design education was learned. The questionnaire developed has five open-ended questions aimed at determining students' motivation and perspective on design education. For the validity of the survey, expert opinion was obtained and final form of the survey was given.

\section{Findings}

This section contains "Who? With Whom? Where? How?" workshop and the survey data.

\subsection{Workshop process: Gamification "Who? With Whom? Where? How?"}

In the workshop, firstly, the game "who, with whom, where" was manually played, the user ID was identified and then it was converted to the function diagram. First of all, A4 papers were distributed to the students. The questions Who? With Whom? Where? and How? were asked, respectively. In each question, the students folded the paper inwards and gave it to the friend next to them. It is forbidden to look at the answers of the questions. They were asked to combine the answers written on the last piece of paper, to form a user ID and write a short text. The written texts were transformed into an enjoyable activity by being read in the class. Afterwards, they carried on with the design process by converting the short text they wrote into a function scheme. 
Table 1. Examples from the game

\begin{tabular}{|c|c|c|c|c|}
\hline Who? & With Whom? & Where? & How? & Results(User ID) \\
\hline $\begin{array}{l}\text { Melisa } \\
\text { (Editor/Publisher) }\end{array}$ & $\begin{array}{l}\text { Lives with her } \\
\text { cousin }\end{array}$ & $\begin{array}{l}\text { A house } \\
\text { with a } \\
\text { garden in } \\
\text { New York }\end{array}$ & $\begin{array}{l}\text { Brown and } \\
\text { purple } \\
\text { colours } \\
\text { house with } \\
\text { game } \\
\text { console. in } \\
\text { game room. }\end{array}$ & $\begin{array}{l}\text { Melisa is an editor. She lives } \\
\text { in the same house with her } \\
\text { cousin. The house is located in } \\
\text { New York. It has a large } \\
\text { garden. The house is } \\
\text { dominated by brown and } \\
\text { purple colors. Melisa loves to } \\
\text { play games with her cousin, so } \\
\text { she has a playroom in her } \\
\text { house. }\end{array}$ \\
\hline $\begin{array}{l}\text { Bahar } \\
\text { (Fashion } \\
\text { Designer) }\end{array}$ & $\begin{array}{l}\text { Sharing the } \\
\text { same house } \\
\text { with a friend }\end{array}$ & In Muğla & $\begin{array}{l}\text { A house } \\
\text { with a } \\
\text { fireplace in } \\
\text { black, pink, } \\
\text { blue colors }\end{array}$ & $\begin{array}{l}\text { Bahar is a fashion designer. } \\
\text { She lives in Muğla with her } \\
\text { friend in a house with a } \\
\text { fireplace dominated by black, } \\
\text { pink and blue colors. }\end{array}$ \\
\hline $\begin{array}{l}\text { Mert } \\
\text { (Teacher) }\end{array}$ & $\begin{array}{l}\text { Lives with his } \\
\text { wife }\end{array}$ & $\begin{array}{l}\text { A house } \\
\text { in the } \\
\text { forest }\end{array}$ & $\begin{array}{l}\text { A house } \\
\text { with a } \\
\text { swing, } \\
\text { dominated } \\
\text { by black, } \\
\text { blue and red }\end{array}$ & $\begin{array}{l}\text { Mert is a teacher. He lives } \\
\text { with his wife in a house in a } \\
\text { wooded area. They have black } \\
\text { lamps, a blue armchair and a } \\
\text { red carpet. There is a rocking } \\
\text { sofa in the lounge of their } \\
\text { house. }\end{array}$ \\
\hline $\begin{array}{l}\text { Sinem } \\
\text { (Student) }\end{array}$ & $\begin{array}{l}\text { Lives with her } \\
\text { family }\end{array}$ & In Norway & $\begin{array}{l}\text { A house } \\
\text { with a pool } \\
\text { (green and } \\
\text { colors) }\end{array}$ & $\begin{array}{l}\text { Sinem lives in Norway with } \\
\text { her mother and father. There } \\
\text { is a pool inside the house. The } \\
\text { furniture is in shades of green. } \\
\text { She preferred a white and } \\
\text { simple design. }\end{array}$ \\
\hline $\begin{array}{l}\text { Aleyna } \\
\text { (Basketball } \\
\text { Player) }\end{array}$ & $\begin{array}{l}\text { Lives with her } \\
\text { husband and } \\
\text { daughter }\end{array}$ & $\begin{array}{l}\text { A house } \\
\text { by the sea, } \\
\text { on the } \\
\text { beach }\end{array}$ & $\begin{array}{l}\text { White house } \\
\text { with gray } \\
\text { walls }\end{array}$ & $\begin{array}{l}\text { Aleyna is a basketball player. } \\
\text { She lives with her husband } \\
\text { and daughter in a house on the } \\
\text { beach. Furnitures in their } \\
\text { homes are white. Some walls } \\
\text { and ceilings are gray. }\end{array}$ \\
\hline
\end{tabular}

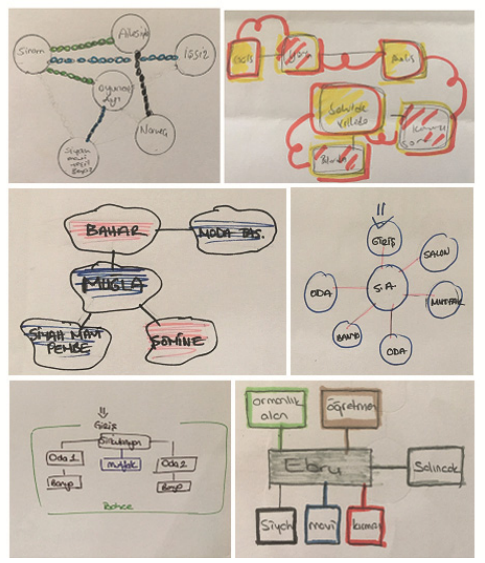

Fig. 1. Examples of diagrams. 


\subsection{Survey: The effect of gamification on the design process}

A survey was applied to determine the effect of gamification on the development of students in the design process. In the survey developed, there are five open-ended questions to determine the students' motivation and view of design education.

Table 2. Survey: The effect of gamification to the design process

\begin{tabular}{|c|c|c|c|c|}
\hline & Question & Yes & No & Student opinions \\
\hline 1 & $\begin{array}{l}\text { Did gamification have a } \\
\text { positive impact on the design } \\
\text { process? }\end{array}$ & $100 \%$ & $0 \%$ & $\begin{array}{l}\text { 'Easier to identify the problem and find a } \\
\text { solution." } \\
\text { "I have learned how to express ideas." } \\
\text { "It made the design process fun. I was able to } \\
\text { follow the lesson, not distracted, not bored" } \\
\text { "I can think more abstract and unusual" } \\
\text { "It made me move faster. I wasn't forced to } \\
\text { know what to do" }\end{array}$ \\
\hline 2 & $\begin{array}{l}\text { Did gamification make it easy } \\
\text { for you to adapt to the design } \\
\text { process? }\end{array}$ & $92 \%$ & $8 \%$ & $\begin{array}{l}\text { "I realized it was more fun." } \\
\text { "I understood how my design started." } \\
\text { "I learned to draw schemes. I learned how to } \\
\text { make a concept map. I learned the function } \\
\text { scheme." } \\
\text { "I learned how to start designing. I have } \\
\text { increased my self-confidence for the project } \\
\text { lessons." } \\
\text { "It made me focus more easily, I'm not bored." }\end{array}$ \\
\hline 3 & $\begin{array}{l}\text { Do you think you've learned } \\
\text { new things about gamification } \\
\text { and design? }\end{array}$ & $100 \%$ & $0 \%$ & $\begin{array}{l}\text { 'I learned what phases of the design process, } \\
\text { first of all, needed to analyze the problem. Then } \\
\text { we drew the schema. When drawing we have } \\
\text { expressed with colored pencils and shapes. We } \\
\text { learned to draw the concept diyagrams." } \\
\text { "I have learned how to express my thoughts to } \\
\text { the others in a simple way, using diyagrams and } \\
\text { concept maps." }\end{array}$ \\
\hline 4 & $\begin{array}{l}\text { 'Do you think that the problem } \\
\text { situation you get from } \\
\text { gamification during the design } \\
\text { process is original?" }\end{array}$ & $75 \%$ & $25 \%$ & $\begin{array}{l}\text { "I'm having trouble finding a subject myself. I } \\
\text { can think different things with this method." } \\
\text { "I came across people and places I couldn't } \\
\text { think of. made me think differently." } \\
\text { "What was written in the game could have been } \\
\text { more interesting, I had difficulty assembling } \\
\text { and writing text" } \\
\text { "It made me gain a different perspective." }\end{array}$ \\
\hline 5 & $\begin{array}{l}\text { Should gamification be used in } \\
\text { design-oriented project lessons? }\end{array}$ & $100 \%$ & $0 \%$ & $\begin{array}{l}\text { "It makes us to learn new things without } \\
\text { memorizing and noticing." } \\
\text { "Allows us to produce original problems." } \\
\text { "We don't usually know what to do when we } \\
\text { start designing. With gamification, we can do } \\
\text { something fun together. Application of other } \\
\text { courses also will make the courses more } \\
\text { interesting." } \\
\text { "We work together as a group. Nobody stays } \\
\text { back. We know each other and work } \\
\text { harmoniously." }\end{array}$ \\
\hline
\end{tabular}


All the students stated that gamification contributed to the design process and the determination of the problem situation in this process. While $92 \%$ of the students stated that they were more easily adapted to the course, $75 \%$ stated that they obtained a more original problem situation. All the students agree that gamification teaches them new knowledge and methods, and they think that the use of gamification in design-focused courses from now on will be beneficial.

\section{Conclusion}

When the survey data were evaluated, it was seen that gamification method increased students' motivation and contributed to multiple alternative propositions in the design process compared to the traditional thinking methods. Thanks to gamification, which is an informal learning method, students learned the concept maps and function schemes used in the design process and the progress of the process without memorization. It was seen that the different disciplines used contributed to the courses in which students had difficulty. The students learned while having fun as a group, all the students participated in the course and did not have any problem of concentration. Gamification was used as a tool in the problem determination process within the workshop study and brought an interdisciplinary dimension to the design education. In addition to being a new learning method, it was a creative and enjoyable activity for students. The integration of a game into design education provides students with a design approach that is far from memorization. As a result of the study, when the data obtained are evaluated, it is concluded that this education model applied to Interior Architecture education can be used as a method that contributes to the learning environment of students in the design process.

\section{References}

1. S. Aydinlı, An approach to architectural education based on hermeneutical understanding., ACTA Politechnica Scandinavia, 105, 97-101, (1996)

2. B. Denel, Temel tasarım ve değişim, N. Teymur \& TA Dural (Eds.), Temel Tasarım/Temel Eğitim, 29-34, (1998)

3. N. Cross, Design research: a disciplined conversation. Design Issues, 15(2), 5-10, (1999)

https://www.jstor.org/stable/pdf/1511837.pdf?refreqid=excelsior\%3A92644f527084ca1 930063a3556aa4128

4. E. Çubukçu, Ş. G. Dündar, Can creativity be taught? An empirical study on benefits of visual analogy in basic design education, $A \mid Z$ ITU Journal of the Faculty of Architecture 4(2), 67-80, (2007). https://www.journalagent.com/itujfa/pdfs/ITUJFA81905-DOSSIER_ARTICLES-CUBUKCU.pdf

5. G. P. Sarığlu Erdoğdu, Basic design education: A course outline proposal. Journal of Planning, 26(1),7-19, (2016)

http://planlamadergisi.org/eng/jvi.aspx?pdir=planlama\&plng=eng\&un=PLAN-52714

6. T. Düzenli, E. M. Alpak, G. D. Özkan, Peyzaj Mimarliğinda Temel Tasarim Dersinin Öğrenme Ve Yaraticilik Sürecine Etkileri. Electronic Journal of Social Sciences, 16, (2017) https://dergipark.org.tr/download/article-file/348609

7. Ö. Kararmaz, A. Ciravoğlu, Integration of the Experience-Based Approaches with the Early Phase Architectural Design Studios. Megaron, 12(3), (2017) 
https://media.proquest.com/media/hms/PFT/1/GQx46?_s=vaPkLDXkvZGh7VfobAdxI uKRptw\%3D

8. S. D. Ozturk, A., Besgen, N. Kuloglu, Rethinking Basic Design Education: Deconstruction of Anatolian Carpets. ART-SANAT, 9, 463-478, (2018)

9. B. Bostancı, B. Akbulak, E. A. Yalçın, Müziğin Forma Dönüşümü: Mimarlık Temel Tasarım Eğitimi. Abant İzzet Baysal Üniversitesi Ĕ̆itim Fakültesi Dergisi, 16 (İpekyolu Özel Say1s1), 2196-2207, (2017)

http://efdergi.ibu.edu.tr/index.php/efdergi/article/download/2189/3190

10. N. Pelling, The (short) prehistory of gamification. Funding Startups (\& other impossibilities), 9, (2011)

11. S. Sezgin, (Kitap Özeti) Öğrenme ve öğretimin oyunlaştırılması: çalışma ve eğitim için oyun tabanlı yöntem ve stratejiler, Açıköğretim Uygulamaları ve Araştırmaları Dergisi, 2(1), 187-197, (2016) https://dergipark.org.tr/download/article-file/401408

12. D. Kayımbaşığlu, B Oktekin, H. Hacı, Integration of gamification technology in education. Procedia Computer Science, 102, 668-676, (2016) https://www.sciencedirect.com/science/article/pii/S1877050916326400

13. İ. Yıldırım, S. Demir, Gamification and education Oyunlaştırma ve Eğitim. Journal of Human Sciences, 11(1), 655-670, (2014)

https://j-humansciences.com/ojs/index.php/IJHS/article/view/2765/1272

14. J. J. Lee, J. Hammer, Gamification in education: What, how, why bother?. Academic Exchange Quarterly, 15(2), 146, (2011) 